\title{
THE ROTTEN, THE SICK AND THE WELL: GENEALOGÍA CONRADIANA DE LO MORBOSO EN THE GREAT GATSBY
}

\author{
THE ROTTEN, THE SICK AND THE WELL: A CONRADIAN \\ GENEALOGY OF THE MORBID IN THE GREAT GATSBY
}

Eduardo Valls Oyarzun

Universidad Complutense de Madrid

evallsoy@ucm.es

\section{RESUMEN}

El presente artículo examina un elemento poco tratado en la relación de influencia de Joseph Conrad (1857-1924) sobre The Great Gatsby (1925), de Francis Scott Fitzgerald, a saber: la estructura, el desarrollo y el alcance ideológico de la metáfora de lo morboso como manifestación de la disfuncionalidad implícita en los sistemas sociales que no observan el principio de responsabilidad. El artículo presenta un marco teórico en el que se definen las líneas maestras del concepto de responsabilidad conradiano, que es análogo, como se sostiene en el artículo, al concepto de responsabilidad promovido por Friedrich Nietzsche, y mantiene diferencias cruciales con el concepto de Thomas Carlyle (1795-1881). El referido marco se emplea para indagar en el campo tropológico de la enfermedad y la podredumbre en la novela de Francis Scott Fitzgerald. A modo de conclusión se abordan las diferencias entre responsabilidad social y responsabilidad individual como elemento diferenciador de los principios ideológicos que entran en conflicto en la novela.

Palabras Clave: Joseph Conrad; F. Scott Fitzgerald; Friedrich Nietzsche; responsabilidad; ideología. 


\section{Abstract}

This article examines an element that has rarely been tackled by critics when discussing the influence of Joseph Conrad (1857-1924) on Francis Scott Fitzgerald's The Great Gatsby (1925), to wit: the structure, development and ideological scope of the idea of the "morbid" as representation of dysfunctional communities that do not observe the principles of responsibility. The article posits a theoretical framework that develops the main features of Conrad's idea of responsibility, which, in turn, resembles that of Friedrich Nietzsche and deviates notably from that of Thomas Carlyle (1795-1881). The said framework is then deployed in order to delve into the images of sickness and rottenness in Fitzgerald's novel. As a conclusion, the article examines the difference between two sorts of responsibility: social and individual, for they are the main constituents of the ideological conflicts the novel features.

KeY-words: Joseph Conrad; F. Scott Fitzgerald; Friedrich Nietzsche; responsibility; ideology.

\section{ENTRE LA TRAICIÓN Y LA RESPONSABILIDAD}

En la nota introductoria a Lord Jim, Joseph Conrad reflexionaba, en tono de perplejidad, sobre una peculiar respuesta crítica que había recibido de su novela:

A friend of mine returning from Italy had talked with a lady there who did not like the book. I regretted that, of course, but what surprised me was the ground of her dislike. You know," she said, "it is all so morbid." The pronouncement gave me food for an hour's anxious thought. Finally I arrived at the conclusion that, making due allowances for the subject itself being rather foreign to women's normal sensibilities, the lady could not have been an Italian. I wonder whether she was European at all? In any case, no Latin temperament would have perceived anything morbid in the acute consciousness of lost honour (CONRAD, 1996: 6).

Dando por sentado que la dama sí era italiana, la crítica debe enfrentarse con la posibilidad de que Conrad estuviera equivocado, es decir, de que el temperamento italiano sí pueda llegar a percibir un rastro de morbosidad en «the acute conciousness of lost honor». La clave de este problema se encuentra, a mi entender, en el programa ideológico que ampara la noción de honor. Conrad situaba el concepto de honor en el centro temático de la novela. Y algo de razón tenía. Los exegetas, sin embargo, desde Chesterton a Ian Watt o Norman Sherry, no pudieron superar la frustración provocada por el escaso alcance explicativo que ofrecía el comentario de Conrad. Así, el comentarista conradiano ha preferido poner el énfasis en las implicaciones ideológicas que suele traer consigo el idealismo inherente al concepto de honor. Ahora bien, el problema no se acaba aquí: ¿qué le molestaba a la turista italiana que descalificaba, por morbosa, la novela de Conrad? Si el temperamento italiano comprende bien la aguda «conciencia del honor perdido», ¿de dónde surge la incomodidad insana que el texto suscitó en la lectora? El sustrato morboso de Lord Jim es parecido, pero no igual, al de Heart of Darkness, y tiene que ver con la simpatía que muestra 
Marlow (el narrador en ambos casos) hacia los personajes principales de ambas narraciones. Hillis-Miller describe la problemática de Lord Jim en los siguientes términos:

Jim is "one of us", an Englishman, son a country clergyman, a "gentleman", brought up in the British tradition of duty, obedience, quite faithfulness, and unostentatious courage. Nevertheless, he has committed the dishonourable act of deserting his ship and the helpless pilgrims she carried. Jim's desertion seems especially deplorable to Marlow, because Jim looks so trustworthy, so perfect an example of the unassuming nobility of the tradition from which he has sprung (...) "He looked as genuine as a new sovereign, but there was some infernal alloy in his metal" [says Marlow in chapter 5]. The discrepancy between what Jim looks like and what he is puts in question for Marlow: "the sovereign power enthroned in a fixed standard of conduct". He does not doubt the existence of the standard, the seaman's code of fidelity, obedience and obscure courage on which the British Empire was built. He comes to question the power installed behind this standard and within it. This power, as its defining adjective affirms, justifies the standard as its king —its principle, its source, its law (HILLIS-MILLER, 1982: 135).

El caso de Kurtz es más elocuente. Michael Lenvenson lo describe así:

The prelapsarian Kurtz had talked of pity, science, progress, love, justice, and the conduct of life (...). They constitute an ideology of enlightenment, a collective moral inheritance which, plainly enough, arouses virtuous aspiration and then proves unequal to the passion it excites (LEVENSON, 1991: 52-53).

Levenson pinta a Kurtz como uno de los representantes más aventajados de la Ilustración, la «causa encomendada por Europa» (CONRAD, 1999: 75). Es, sin embargo, durante su viaje por el río Congo, cuando se abre la brecha que separa las dos imágenes que se dan del personaje ${ }^{1}$ en la novela breve. Las esperanzas de civilización de Kurtz se transforman en una serie de cualidades primarias, animales e instintivas que apelan al poder como fin en sí mismo por encima de todo. Características estas que se corresponden mejor con el ultrahombre nietzscehano que con el ideal ilustrado (VALLS OYARZUN, 2017: 223-238).

El espacio común que reúne a Kurtz y Jim es la traición. Ambos personajes, en sus respectivas novelas, se exponen a aquello que Albert J. Guerard denomina los «poderes oscuros» (GUERARD, 1958: 154), la presencia de un elemento terrible, pero real, que se opone al libre desarrollo de la conciencia: la jungla en el caso de Kurtz y la marginación del semejante en el caso de Jim. Ambos personajes, también, sucumben ante ellos, provocando un cambio cualitativo en su actitud para con el sustrato ideológico que ha dado forma cabal a sus conciencias. Desde ese momento crítico, ambos personajes pasan a justificar sus acciones por causa de su propia conciencia individual: esto es, solo adquieren compromisos

\footnotetext{
${ }^{1}$ Conrad se cuida mucho de presentar estas imágenes en un juego de paralelos acorde con la estructura del relato. La información sobre el Kurtz anterior a su experiencia africana se conoce en la misma medida en que se va descubriendo al Kurtz posterior a dicha experiencia, y no se completa una imagen satisfactoria de ambos personajes hasta el encuentro final de Marlow con la prometida de Kurtz. La administración de la información, en este, como en otros casos, va encaminada a subrayar la dicotomía parentesco-alteridad que, a mi juicio, preside el relato.
} 
y devengan responsabilidades para consigo mismos. Con todo, la traición a dicho sustrato ideológico, el cual se describirá más adelante, es de distinto signo según la novela. En el caso de Kurtz, se pasa del idealismo victoriano basado en la fe, la idea de progreso, el sentido utilitarista del deber y la ética del trabajo a una concepción telúrica, titánica y poderosa —ultrahumana en una palabra— del yo (VALLS OYARZUN, 2017: 47-50). Así, la actitud de Kurtz está muy cerca de los siguientes comentarios de Nietzsche:

Pero lo que más hace que al gusto actual le resulte extraña y penosa una moral de dominadores es la tesis básica de esta de que solo frente a los iguales se tienen deberes; de que, frente a los señores de rango inferior, frente a todo lo extraño, es lícito actuar como mejor parezca, o "como quiera el corazón», y, en todo caso «más allá del bien y del mal». (...) Un hombre que aspire a cosas grandes considera a todo aquel con quien se encuentra en su ruta, o bien como un medio, o bien como una rémora y obstáculo, —o bien como un lecho pasajero para reposar. Su peculiar bondad, de alto linaje, para con el prójimo solo es posible cuando él está en su altura y ejerce dominio (NIETZSCHE, 1993: 238 y 256).

El caso de Jim constituye un proceso de traición distinto. Albert Guerard lo describe de forma muy precisa: «A man is born ready to create an idealized conception of the self, an ego-ideal. If he tries to escape or trascend this conception of self, he collapses. He should accept this ideal and try through action to make it 'viable'»(GUERARD, 1958: 156). Mientras Kurtz traiciona el ideal victoriano al no resistir la alienación progresiva de su propia conciencia, lo cual deviene en su posterior fusión con la jungla, Jim comete parecida transgresión manteniéndose fiel a la concepción ultra-idealista de su propio ego. ¿Dónde están, en este caso, las reglas de honor que dicta la comunidad?; perdidas, como dice Conrad. El honor es parte constitutiva de la ley que mencionaba Hillis-Miller, pero si no se compadece con el programa autorreferencial que se genera en la conciencia del personaje, entonces no tiene cabida en el compromiso al que, Jim en este caso, debe fidelidad. Ambas figuras, en resumen, traicionan a la comunidad para proclamar la emancipación absoluta de su conciencia individual.

La turista italiana que alude la cita con la que se inicia este artículo ya tiene aquí dos claros motivos para poder descalificar, por morbosas, tanto a Lord Jim como a Heart of Darkness, pero aún podrá cargarse de más razones, pues si busca consuelo ideológico en la figura del narrador, Marlow, al cabo del día solo podrá sentirse desilusionada. Permítaseme una digresión para aclarar este extremo.

El siglo diecinueve fue muy prolífico en lo tocante a la creación de héroes. El que mejor impresión causó en la conciencia romántica inglesa fue, claro, el héroe byroniano. Y digo bien, en la conciencia romántica, porque el grueso pellejo de la conciencia victoriana mostró, por el contrario, cierta resistencia a dejarse permear por la figura del héroe byroniano. Para este otro tipo de conciencia, el héroe byroniano resultaba demasiado fuerte, en el sentido nietzscheano del término, es decir, demasiado cerca de la realidad de la vida, por lo que la conciencia victoriana y su cultura normativa tuvo que domarlo a fin de poder incorporarlo plenamente a su discurso. Así, la conciencia victoriana promovió un arquetipo distinto opuesto al modelo byroniano. Este fue el modelo que Thomas Carlyle expuso en sus ensayos On Heroes (Sobre los héroes, 1841). Ambos modelos, el byroniano y el car- 
lyleano, están, no obstante, relacionados entre sí. Como bien sostienen Eric Bentley (1947: 42) y, a su manera, Mario Praz (1956: 48), La característica común que comparten el héroe byroniano y los «grandes hombres», esto es, los héroes de Carlyle, es que ambos, manifiestan una voluntad esencial por convertirse en emblemas del mundo, es decir, en símbolos de la realidad. Carlyle, Byron y, más tarde, Nietzsche coinciden principalmente en que el héroe constituye una proyección factual del sustrato profundo del ser. Pero mientras Byron y Nietzsche entienden el sustrato dionisiaco y la voluntad de poder como fuerzas vitalistas inaprensibles, contenidas o formadas por un devenir que escapa al alcance de la conciencia, Carlyle aboga por un principio absoluto, fijo e inmutable que dé sentido al flujo evolutivo de la historia y que sea posible aprehender de manera intuitiva (VALLS OYARZUN, 2017: 89 y ss.). Nietzsche y Byron aceptan la realidad de la vida sin preocuparse por una supuesta justificación metafísica que le dé sentido. Carlyle, en cambio, defiende un ideal supremo que, curiosamente, no puede ser aprehendido por medio del discurso histórico que emplea. «¿Cómo? ¿Un gran hombre?», espeta Nietzsche en clara referencia a Carlyle, «yo veo siempre tan solo al comediante de su propio ideal» (NIETZSCHE, 1993: 103). A partir de ese ideal supremo, Carlyle deriva las ideas de fe, sentido del deber y progreso. Esto es así por causa de una cualidad esencial y definitoria del héroe, quien se ve obligado a contraer una responsabilidad para con el sustrato divino. Su deber es velar porque dicho sustrato, la verdad, se mantenga como fuente y origen de las relaciones heterónomas que rigen la comunidad a la que sirve (VALLS OYARZUN, 2017: 90). Y esta, a su vez, debe hacer su propio ejercicio de heroicidad reconociendo el origen divino del poder que sostiene al héroe. Nietzsche y Byron, como quiera que niegan la posibilidad de semejante ideal, esto es, el sustrato divino, no contemplan esa característica en el cuadro de virtudes de sus héroes. Carlyle busca algo en lo que tener fe tanto como Nietzsche busca desligarse del idealismo: «Mi fórmula para expresar la grandeza en el hombre es amor fati; el no querer que nada sea distinto ni en el pasado ni en el futuro ni por toda la eternidad. No solo soportar lo necesario, y aun menos disimularlo — todo idealismo es mendacidad frente a lo necesario —, sino amarlo» (NIETZSCHE, 1996: 61; la cursiva es mía). Por eso, Nietzsche se toma tantas molestias para desligar su modelo ultrahumano del llamado culto a los héroes (NIETZSCHE, 1996: 65).

Carlyle empieza su propuesta donde Byron dejó la suya (BENTLEY, 1947: 97 y 99). El héroe de Carlyle conserva parte de las sinergias nietzscheanas del prototipo byroniano (aristocracia, nobleza, crueldad), pero las actualiza insertándolas en un discurso que también participa tanto de los valores como de los presupuestos ideológicos victorianos: fe, sentido del deber, es decir, responsabilidad social e idea de progreso. Por esta razón, la propuesta de Carlyle se asienta muy bien en la conciencia colectiva del período victoriano. Ahora bien, nótese que esa propuesta, de carácter idealista, tiene un origen ajeno al individuo. Es idealismo, sí, pero no es el idealismo de un, por ejemplo, Lord Jim, pues se funda en un principio que genera las relaciones heterónomas que definen una comunidad, llámese nación, sociedad o como se quiera. Los Jim no asumen responsabilidades para con un principio comunitario, divino, es decir, un principio ajeno, sino para con una concepción ideal de su propio yo. En palabras de Robert Hampson: «Jim has arranged his life in such a way that his identity-for-self is a secret self that is deliberately prevented from realisation in order to protect it from challenges from reality» (HAMPSON, 1992: 120). 
En resumen, la idea del mundo que profesa el Gran Hombre de Carlyle se deriva de un principio fijo, ideal e inmutable (la divinidad) que el propio Carlyle interpreta como el sustrato último de la realidad. El héroe de esta estirpe devengará responsabilidades para con ese ideal. El realismo (Kurtz), o, para el caso, también el idealismo que tome como referencia no tanto el principio de divinidad, cuanto el sujeto individual, como sería el caso de Jim, sería, según Carlyle, falso por necesidad.

El antagonismo entre el «gran hombre» carlyleano y el héroe byroniano dio pie a una oposición dialéctica muy productiva desde el punto de vista literario: la oposición entre el héroe carlyleano y el villano byroniano, que no sería ya héroe, pues representaría una opción falsa desde el punto de vista de la divinidad (VALLS OYARZUN, 2017: 85-87 y 121123). En todos estos casos, sin embargo, se propone como síntesis la sublimación deletérea del elemento byroniano a favor, siempre, del elemento carlyleano. Y como este elemento encarna, recuérdese, los componentes ideológicos de la comunidad victoriana, puede argüirse que la dialéctica fundamental que acabo de mencionar forma parte del canon de grandes relatos del sustrato ideológico victoriano (VALLS OYARZUN, 2017: 170-171)2.

Las dos grandes narraciones de Marlow (Heart of Darkness y Lord Jim) siguen el patrón dialéctico: un héroe carlyleano comprometido con los valores victorianos que denuncia y combate la traición del villano byroniano, desarrollado según los principios arriba mencionados. No obstante, ambos relatos incluyen una diferencia crucial en el proceso dialéctico: la responsabilidad que Marlow asume para con los dos protagonistas de sus narraciones, hace que aquel, Marlow, acabe por dudar del principio inmutable que determina la perspectiva de su visión del mundo, de facto sustituyendo su compromiso con lo divino, en tanto representante de la heroicidad à la Carlyle, por un compromiso con la «otredad»; o dicho de otro modo, sustituyendo la responsabilidad comunal del héroe carlyleano por otro tipo de responsabilidad, o compromiso con el yo individual. En pocas palabras, Marlow encarna el fracaso del héroe carlyleano como origen del gran relato victoriano. Y, claro, si el origen del gran relato está viciado, es lógico que los lectores adscritos a la ideología que sustenta dicho relato (por ejemplo, la acomodada turista italiana), perciban las narraciones de Marlow como un elemento morboso dentro del sistema.

2 Esta relación puede rastrearse en varias novelas del medio siglo diecinueve. Veánse unos ejemplos ilustrativos. David Copperfield, en la novela epónima de Charles Dickens busca reafirmar su condición de héroe como hombre de letras al denunciar la falsedad de los idólatras 3/4el término es de Carlyle (1966: 121-122)3/4 Uriah Heap (una curiosa reencarnación del «sacerdote» de «la moral de los esclavos» nietzscheana) y Steerforth y reconocer así el carácter de emblema divino de su amada Agnes. En A Strange Story (1861), de Edward Bulwer Lytton, Allen Fenwick hace lo propio denunciando y combatiendo la condición de falso héroe de Margrave (una curiosa reencarnación esotérica del villano byroniano). Igual suerte corre la reina Ayesha o She-who-must-beobeyed (villana byroniana, pero también acaso la primera ultramujer de la historia de la literatura inglesa) a manos de Leo Vincey y su tutor Horace en She (1887) de Henry Rider-Haggard. Y, en fin, lo mismo puede decirse de Hartright y Fosco en The Woman in White (1861) de Wilkie Collins, Jim y Long John Silver en Treasure Island (1883), etc. (VALLS OYARZUN, 2017: 121-170). 


\section{UN ALUMNO AVENTAJADO}

Parece haber común acuerdo entre los críticos de Scott Fitzgerald a la hora de calificar a Conrad — las más veces en compañía de Eliot (BICKNELL, 1954: 80)— como la influencia más determinante en la composición de The Great Gatsby. Así piensan James E. Miller (1957: 237 y ss.), Ronald Berman (1996: 152, 63; 2002: 79-80), Tony Tanner (1990: XX), John Bicknell (1954: 88-90), Robert W. Stallman (1955: 124), Arthur Mizener (1946: 184), Matthew Bruccoli (1981: 176,181-184, 211 y ss.) o Nicolas Tredell (1997: 60-66), entre otros. El consenso se rompe, sin embargo, cuando los comentaristas intentan descubrir qué obra de Conrad resuena más, o mejor, en la novela de Fitzgerald. Arthur Mizener, por ejemplo, opina que «la mutación del narrador en primera persona» (es decir, la alternancia entre el $I$ y el We al final de la novela) debió ser un préstamo de The Nigger of the Narcissus (1946: 185). Miller y Tanner, en cambio, creen que la voz narrativa, así como la distancia que esta toma con respecto del personaje central, está más influida por la lectura de Lord Jim, Heart of Darkness y Chance, las tres novelas de Marlow (MILLER, 1957: 240; TANNER, 1990: XX). Berman otorga una importancia crucial a Almayer's Folly y se olvida de su hermana mayor: Lord Jim (BERMAN, 2002: 80). Otros solo advierten el «tono conradiano» que resuena en pasajes concretos de la novela (en la descripción del «Valley of Ashes» que abre el capítulo segundo, por ejemplo), pero se olvidan de identificar la fuente de donde proviene ese tono SELDES (2005: 211). Curiosamente, solo Robert Stallman trata la influencia de Nostromo con la debida seriedad (1955: 124 y ss.), a pesar incluso de que Fitzgerald llegó a calificar el libro como «The greatest novel since Vanity Fair (possibly excluding Madame Bovary)» (cfr. STALLMAN, 1955: 125). El análisis de Stallman es bastante elocuente, por cuanto pone de manifiesto la hipertrofia del yo social que sufren tanto Gatsby como Gian Battista Fidanza «Nostromo».

Fitzgerald pudo aprender de Conrad todas esas cosas y algunas más: por ejemplo, el elemento morboso de los relatos de Marlow. Según Susan Resneck Parr:

Nick's choices, perhaps even more than those of the other characters, are affected by his sense of vulnerability, on the one hand, and his desire for order, on the other. Throughout the novel, his narrative is dominated by his ambivalence about whether it is better to embrace life's possibilities or to try to escape from its uncertainties and dangers. And so, although events lead to Nick to be increasingly wary of change and to yearn for a world that is "in uniform and at a sort of moral attention forever", he continues to celebrate Gatsby's "romantic readiness" and his "extraordinary gift for hope" (RESNECK PARR, 2002: 71).

Resneck Parr sostiene que The Great Gatsby es una novela sobre la búsqueda del orden, pero se contradice a sí misma en varios pasajes de su artículo cuando sugiere, como en el caso de Nick, la oposición entre una suerte de pulsión vitalista («life's possibilities») y el deseo de «un orden moral» inmutable. No se olvide: «I was within and without» (FITZGERALD 1990: 53). Lo primero se ilustra, por ejemplo, con la admiración que Nick manifiesta hacia el tono, el timbre y la modulación de la voz de Daisy, un motivo bastante recurrente a lo largo de la novela, por otra parte: 
I looked back at my cousin who began to ask me questions in her low, thrilling voice. It was the kind of voice that the ear follows up and down as if each speech is an arrangement of notes that will never be played again. Her face was sad and lovely with bright things in it, bright eyes and a bright passionate mouth-but there was an excitement in her voice that men who had cared for her found difficult to forget: a singing compulsion, a whispered "Listen," a promise that she had done gay, exciting things just a while since and that there were gay, exciting things hovering in the next hour (FITZGERALD 1990: 37).

Nick disfruta con la suspensión de la impresión estética que obtiene del discurso de Daisy. A modo de epifanía, parece haber una fusión entre sujeto perceptor y objeto percibido que, sin embargo, se expresa desde lo efímero del momento. La promesa de «gay, exciting things» sigue al eco pasado de otras «gay, exciting things», pero nunca llega a realizarse en el momento actual del presente. Esa fluidez tan característica de la impresión, del «momento [virginia-woolfiano] del ser», se caracteriza por ser, necesariamente, inaprensible. Ahora bien, quizá por ello — y por su aparición en otros momentos de la novela (FITZGEERALD, 1990: 75, 82 y 83)— se antoja extremadamente atractiva como emblema de la pulsión vitalista de Nick.

La fusión entre sujeto y objeto cancela la posibilidad de una reflexión consciente sobre la experiencia etérea de la voz de Daisy. Se trata, por tanto, de una experiencia preterracional, imbricada en un sustrato de imposible aprehensión desde el espacio apolíneo de la conciencia. De tener mayor alcance trágico, Nietzsche lo denominaría un momento de «sabiduría dionisiaca» (NIETZSCHE, 1994: 74).

Este momento íntimo contrasta con la expresión más elocuente del deseo de orden de Nick. Al final del capítulo III, tras un episodio, bastante significativo, por otra parte, y del cual me ocuparé un poco más adelante, Nick se define en los términos siguientes: «But I am slow-thinking, and full of interior rules that act as brakes on my desires, and I knew that first I had to get myself definitely out of that tangle back home» (FITZGERALD, 1990: 59). Al contrario que en la cita anterior, llama la atención cómo esas «interior rules» a las cuales Nick parece reprochar su absoluta imposibilidad para funcionar desde la inestabilidad y la incertidumbre, no se perciben como propias de la personalidad, sino más bien como ajenas a ella. La expresión de este pasaje no pone el énfasis en la fusión del sujeto perceptor (la conciencia) y el objeto percibido (el deseo), sino, más bien, en la inarticulación de ambos. El espacio que intenta representar Nick es, en este caso, el espacio apolíneo.

Hago la distinción de los espacios de la conciencia en términos Nietzscheanos por una razón muy concreta. Valga otra digresión para clarificar este extremo. El filósofo alemán define el espacio de la conciencia en el Gay saber:

La evolución del lenguaje y la evolución de la conciencia (no de la razón, sino solo del hacerse-consciente de la razón) van de la mano. (...) El hacerse conscientes nuestras impresiones sensibles en nosotros mismos, tiene energía para poder grabarlas e inmediatamente situarlas fuera de nosotros, tomada en la medida en que crecieron las instancias de transmitirlas a los demás mediante signos. El hombre como inventor de signos es al mismo tiempo el hombre cada vez. más agudamente consciente de sí mismo. Solo en cuanto animal social aprende el hombre a ser consciente (NIETZSCHE, 2001: 478). 
La conciencia es, según Nietzsche, el espacio del «entre», el terreno fronterizo de la personalidad y la dimensión social del hombre. Aquella solo evoluciona en el ser humano por cuanto hay una red de individuos que necesita estructurarse como ente único e independiente. Por si fuera poco, el concepto de la responsabilidad, en Nietzsche, resulta crucial para el desarrollo de la conciencia como espacio del «entre». La capacidad de hacerse responsable, según Nietzsche, se ha transformado, con el paso del tiempo, en un instinto dominante denominado «conciencia»:

El orgulloso conocimiento del privilegio extraordinario de la responsabilidad, la conciencia de esta extraña libertad, de este poder sobre sí y sobre el destino, se ha grabado en él [el hombre de voluntad libre] hasta su más honda profundidad y se ha convertido en instinto, en instinto dominante: - ¿cómo llamará a este instinto dominante, suponiendo que necesite una palabra para él? Pero no hay ninguna duda; este hombre soberano lo llama su conciencia. (...) Que al hombre le sea lícito responder de sí mismo y hacerlo con orgullo, o sea, que al hombre le sea lícito decir sí también a sí mismo — esto es, como hemos indicado, un fruto maduro (...) (NIETZSCHE, 1987: 78-79).

La conciencia y la responsabilidad son, en sentido estricto, los elementos articuladores de la comunidad, las piezas que definen el espacio «entre» individuos. Ambos conceptos sirven para crear una red de interdependencia que cohesiona las relaciones básicas entre individuos y que sirve, a su vez, a modo de contenedor de los referentes por los cuales se pueden clasificar los distintos tipos de comunidad: relación heterónoma (poder, economía, comunidad como sociedad ${ }^{3}$ ) o relaciones de identidad (comunidad como nación, cuerpo religioso, etc.) $\square$ muchos de estos referentes, como bien señala Maurice Blanchot en su libro The Unavowable Community, deben combinarse para poder intentar definir una comunidad dada con precisión (BLANCHOT, 1998: 17) $\square$.

La consciencia de tener conciencia que demuestra Nick al referirse a sus «interior ru1 les ${ }^{4} \gg$ pone de manifiesto su sentido de comunidad. Su deseo de orden está, por tanto, fuertemente arraigado a esa pertenencia al grupo comunal. Por el contrario, los momentos en que la conciencia de Nick tiende a disolverse, a fundirse con el objeto percibido, los momentos de plenitud individual (Joyce los llamaría epifanías, Husserl fenómenos y Nietzsche «momentos de sabiduría dionisiaca»), se asocian con la pulsión vitalista del narrador.

\footnotetext{
${ }^{3}$ «The community is not the restricted form of a society, no more than it tends toward a communitarian fusion. It differs from a social cell in that it does not allow itself to create a work and has no production value as its aim» (BLANCHOT, 1998: 11).

${ }^{4}$ En otras ocasiones, Nick expresa su pulsión por el orden proyectando en los demás la ansiedad que le produce la incertidumbre del tiempo: «At the enchanted metropolitan twilight I felt a haunting loneliness sometimes, and felt it in others-poor young clerks who loitered in front of windows waiting until it was time for a solitary restaurant dinner-young clerks in the dusk, wasting the most poignant moments of night and life» (FITZGERALD, 1990: 57). De nuevo, el deseo de orden viene asociado al sentido de comunidad. «Yet high over the city our line of yellow windows must have contributed their share of human secrecy to the casual watcher in the darkening streets, and I was him too, looking up and wondering. I was within and without, simultaneously enchanted and repelled by the inexhaustible variety of life» (FITZGERALD, 1990: 37).
} 
La actitud de Nick es, como bien decía Susan Resneck Parr, ambivalente: «Nick's choices, perhaps even more than those of the other characters, are affected by his sense of vulnerability, on the one hand, and his desire for order, on the other» (RESNECK PARR, 2002: 71).

\section{THEN WEAR THE GOLD HAT, IF THAT WILL MOVE HER}

Al igual que Marlow en Lord Jim o Heart of Darkness, Nick presenta una conciencia imbricada en la comunidad a la que pertenece. La diferencia entre ambos radica, en el distinto tipo de comunidad que ampara a los dos narradores y a la actitud diferente que estos tienen hacia aquella. No voy a entrar a discutir las características que definían la identidad victoriana del primero. Baste sin embargo recordar que Marlow representaba el proceso de desestabilización de una conciencia arraigada en los valores de la fe, el sentido del deber, es decir, la responsabilidad social, la ética del trabajo y el culto al progreso. La comunidad a la que Nick da voz es algo distinta.

La comunidad de The Great Gatsby es, no se olvide, el resultado factual del capitalismo especulativo que comienza a practicarse, sobre todo, desde finales del siglo diecinueve y principios del veinte. El mundo de la novela es el punto de llegada de un breve pero intenso proceso evolutivo cuyo inicio acaso tenga su mejor expresión en el mundo descrito por Edith Wharton (The House of Mirth, 1905, por ejemplo). En efecto, la alta aristocracia de origen holandés que pintaba aquella va dando paso a los banqueros, especuladores y arrivistas que pueblan la novela de Fitzgerald. Y no cito esta terna de arquetipos por casualidad, pues el propio texto deja bien claro que no hay diferencia clara entre el empresario capitalista que se sitúa en el marco de la legalidad y el que no. Véase sino la lista de invitados a las fiestas de Gatsby que Nick esboza al inicio del capítulo IV. Préstese atención al tono rabelaisiano de los nombres:

From East Egg, then, came the Chester Beckers and the Leeches and a man named Bunsen whom I knew at Yale and Doctor Webster Civet who was drowned last summer up in Maine. And the Hornbeams and the Willie Voltaires and a whole clan named Blackbuck who always gathered in a corner and flipped up their noses like goats at whosoever came near. And the Ismays and the Chrysties (or rather Hubert Auerbach and Mr. Chrystie's wife) and Edgar Beaver, whose hair they say turned cotton-white one winter afternoon for no good reason at all. Clarence Endive was from East Egg, as I remember. He came only once, in white knickerbockers, and had a fight with a bum named Etty in the garden. From farther out on the Island came the Cheadles and the O.R. P. Schraeders and the Stonewall Jackson Abrams of Georgia and the Fishguards and the Ripley Snells. Snell was there three days before he went to the penitentiary, so drunk out on the gravel drive that Mrs. Ulysses Swett's automobile ran over his right hand. The Dancies came too and S. B. Whitebait, who was well over sixty, and Maurice A. Flink and the Hammerheads and Beluga the tobacco importer and Beluga's girls. From West Egg came the Poles and the Mulreadys and Cecil Roebuck and Cecil Schoen and Gulick the state senator and Newton Orchid who controlled Films Par Excellence and Eckhaust and Clyde Cohen and Don S. Schwartze (the son) and Arthur McCarty, all connected with the movies in one way or another. And the Catlips and the Bembergs and G. Earl Muldoon, brother to that Muldoon who afterward 
strangled his wife. Da Fontano the promoter came there, and Ed Legros and James B. ("RotGut") Ferret and the De Jongs and Ernest Lilly-they came to gamble and when Ferret wandered into the garden it meant he was cleaned out and Associated Traction would have to fluctuate profitably next day (FITZGERALD, 1990: 60-61; la cursiva es mía).

Más elocuente me parece el hecho de que la comunidad que articula Fitzgerald vive de la nada. Esto lo explica el hecho de que los tres elementos dominantes en el mercado de esta comunidad (al menos en el mercado legal) son los bonos, los seguros y los automóviles. El propio Nick, la voz autorizada de la comunidad, ha hecho su viaje al este para dedicarse al negocio de los bonos. Gatsby, por su parte, parece estar metido en negocios fraudulentos que tienen que ver con la venta de bonos en bolsa. Recuérdese el episodio de Parke (Thomas Parke D'Invilliers): "“Young Parke's in trouble," he said rapidly. "They picked him up when he handed the bonds over the counter. They got a circular from New York giving 'em the numbers just five minutes before. What d'you know about that, hey? You never can tell in these hick towns-"» (FITZGERALD, 1990: 158). Los seguros son también parte de la especulación. $\mathrm{O}$ al menos parecen ser un atractivo cebo para los arrivistas más inesperados. En la fiesta del capítulo III, Nick informa de lo siguiente: «I was immediately struck by the number of young Englishmen dotted about; all well dressed, all looking a little hungry and all talking in low earnest voices to solid and prosperous Americans. I was sure that they were selling something: bonds or insurance or automobiles» (FITZGERALD, 1990: 43).

Tanto los bonos como los seguros carecen de valor tangible, es decir, son entidades abstractas a las que se inviste de un valor arbitrario para que fluctúe en función de la marcha de la economía. Ahora bien, esa economía no existe. Bueno, o al menos está elidida de la novela. ¿Qué hay de las fuerzas productivas reales, es decir, de la mano de obra? ¿Y el empresariado industrial? Lo poco que queda de ellas se concentra en el "Valley of Ashes», que da cobijo a la pequeña muestra de clase trabajadora — «the ash-grey men» (FITZGERALD, 1990: 26) — que habita la novela. Ahora bien, el espacio en cuestión no produce nada porque es un terreno yermo, esto es, una «waste land», literalmente, pues así se explicita en la novela:

This is a valley of ashes-a fantastic farm where ashes grow like wheat into ridges and hills and grotesque gardens where ashes take the forms of houses and chimneys and rising smoke and finally, with a transcendent effort, of men who move dimly and already crumbling through the powdery air. Occasionally a line of grey cars crawls along an invisible track, gives out a ghastly creak and comes to rest, and immediately the ash-grey men swarm up with leaden spades and stir up an impenetrable cloud which screens their obscure operations from your sight (FITZGERALD, 1990: 26).

Parece lógico que un sistema que permite las prácticas especulativas sugeridas en el texto, debió generar, en tiempo pasado al de la novela, cuotas de productividad bastante notables. Pero insisto, los sectores económicos realmente productivos son obscenos, esto es, permanecen fuera de la escena. En estas circunstancias, el capital en forma dinero suele perder buena parte, si no todo su valor real, lo cual, a su vez, genera una fractura casi insalvable en el ciclo del capital que acaba por paralizar sus elementos colapsando el sistema. 
Justo esto ocurrió tres años después de la publicación de la novela, por cierto. Cuando el objeto producido aparece en la novela lo hace siempre en forma de bien de consumo, es decir, alienado de la fuerza productiva. Además, en la mayoría de casos, ese bien de consumo suele poner fin al ciclo del capital. El consumidor compulsivo que puebla las páginas del libro resulta ser, por tanto, un atesorador en el sentido marxista del término ${ }^{5}$, es decir, una fuerza económica estéril que desactiva las posibilidades reales del sistema económico al que pertenece. El caso más claro es Myrtle Wilson:

"My dear," she cried, "I'm going to give you this dress as soon as I'm through with it. I've got to get another one tomorrow. I'm going to make a list of all the things I've got to get. A massage and a wave and a collar for the dog and one of those cute little ash-trays where you touch a spring, and a wreath with a black silk bow for mother's grave that'll last all summer. I got to write down a list so I won't forget all the things I got to do" (FITZGERALD, 1990: 38).

El oro, el patrón de cambio que otorga valor al dinero, es decir, que le dota de significado, está disperso por toda la novela ${ }^{6}$. Y su aparición suele subrayar una presencia vacua, exenta de valor real, esto es, un gesto, una apariencia. El ritmo cromático de la novela abusa del color amarillo, el bronce, el dorado y los tonos pajizos en momentos que suelen asociarse, bien con la muerte, bien con la tremenda (por honesta) futilidad de la vida: el

5 «El constante movimiento cíclico de las dos metamorfosis antagónicas de las mercancías o la continua sucesión de ventas y compras se revela en la circulación infatigable del dinero o en su función de perpetuum mobile de la circulación. El dinero se inmoviliza o se convierte (...) de mueble en inmueble, de moneda en dinero, tan pronto como se interrumpe la serie de metamorfosis, tan pronto como la venta no se complementa con la compra que normalmente le sigue. En cuanto comienza a desarrollarse la circulación de mercancías, comienza a desarrollarse también la necesidad y la pasión de retener el producto de la primera metamorfosis, la forma transfigurada de la mercancía, o sea, la crisálida dinero. Ahora, las mercancías se venden no para comprar con su producto otras, sino para sustituir la forma mercancía por la forma dinero. De simple agente mediador del metabolismo este cambio de forma se convierte en fin último. La forma enajenada como su forma absolutamente enajenable, como su forma dinero, llamada constantemente a desaparecer. El dinero se petrifica, convirtiéndose en tesoro, y el vendedor de mercancías en atesorador» (MARX, 1999: 88).

${ }^{6}$ Sin clase trabajadora, es decir, sin nivel productivo, el sistema económico del Nueva York de la novela debería ser, cuando menos, inestable. Pero no lo parece. El ciclo de transformación del capital ha obturado las vías de producción en los sectores primario y secundario y funciona ya solo en el ámbito del sector financiero. Esta circunstancia importa en tanto el capital en forma mercancía del sector financiero (el dinero) no constituye una realidad tangible producida, sino más bien un concepto relativo, pretendidamente objetivable, que se sostiene por un sistema de cambio arbitrario. En 1926, el «correlato (pretendidamente) objetivo» del dinero era el oro (y digo pretendidamente objetivable porque el valor del oro, para este caso, no es un valor de uso, sino un valor de cambio). Entre 1870 y 1890 Gran Bretaña sufrió el período de la «Larga Depresión» («The Long Depression») o período de Gran Deflación, durante el cual bajó el precio del dinero favoreciendo así el desarrollo del mercado financiero americano. Poco antes de la primera guerra mundial, sin embargo, la reserva federal norteamericana percibía señales de que ese mismo proceso de deflación continua podía suceder en EE UU y el patrón oro suponía un impedimento, más que una ayuda, ante dicha coyuntura. En 1913, por tanto, la Reserva Federal promovió el abandono del oro como patrón de cambio. Pero la crisis económica que sufrió el imperio británico durante la primera guerra mundial hizo aconsaejable que los EE UU mantuvieran el patrón oro (bajó el precio del oro, bajó la libra, pero no el dólar). Este debate sobre si continuar o no con el patrón oro fue muy popular en la capital financiera de EE UU, Nueva York durante los años veinte. En cierto modo, The Great Gatsby se hace eco del debate sobre el patrón oro, pero, sin duda alguna, el texto satírico que mejor rédito sacó a tan larga disputa sobre el patrón oro se había publicado veintiséis años antes: The Wonderful Wizard of Oz (1900). 
Rolls de Gatsby es amarillo, el torneo en el que Jordan hizo trampas fue su «first gold tournament» (FITZGERALD, 1990: 58), las luces brillantes de la casa de Gatsby atraen a una colosal pléyade de parásitos, los asientos del tren que cruza por el valle de cenizas son de paja, el lápiz dorado de Daisy, el brazo broncíneo de Jordan, «and in the lamplight downed with light brown hair» (ELIOT, 1993: 16), los anteojos amarillos del Dr. T. J. Eckleburgh, etc. Y si el oro no aparece de forma explícita, entonces se diluye en el texto de forma implícita, deconstruído en caracteres concretos que recuerdan siempre su presencia, de suerte que la novela está llena de «glints», «glows», «brightness», etc. ${ }^{7}$

Mención aparte merecen los automóviles. Puede argüirse que el sector del automóvil sí es un sector productivo. (Ninguna novela modernista supera, en número y presencia de automóviles, a The Great Gatsby). Pero no menos cierto es que dicho sector se halla en una posición extremadamente singular dentro del ciclo del capital que sostiene la sociedad de la novela. Los automóviles en la novela tienen más valor de cambio que valor de uso, es decir, sirven más como símbolo de riqueza y posición social (falsa en muchas ocasiones) que como elemento práctico de transporte:

A dead man passed us in a hearse heaped with blooms, followed by two carriages with drawn blinds and by more cheerful carriages for friends. The friends looked out at us with the tragic eyes and short upper lips of south-eastern Europe, and I was glad that the sight of Gatsby's splendid car was included in their somber holiday. As we crossed Blackwell's Island a limousine passed us, driven by a white chauffeur, in which sat three modish Negroes, two bucks and a girl. I laughed aloud as the yolks of their eyeballs rolled toward us in haughty rivalry (FITZGERALD, 1990: 67).

La utilidad del coche en la novela es relativa. Tom y Nick parecen ser más aficionados al viaje en tren. La línea que ambos frecuentan, por cierto, también transporta una buena cantidad de «East eggers», esto es, los ciudadanos más ricos de entre las dos penínsulas, razón suficiente para que Tom persuada a su amante de que debe ir en un vagón distinto al suyo). Además, muchos de los invitados de Gatsby hacen uso del Rolls Royce de su anfitrión para desplazarse a las fiestas, como si fuera un simple coche de línea (algo extraño para la turba de nuevos ricos que puebla las fiestas de Gatsby). Y no son pocos los que también viajan en tren para asistir al entretenimiento: «On week-ends his Rolls-Royce became an omnibus, bearing parties to and from the city, between nine in the morning and long past

\footnotetext{
7 En lo que al oro se refiere, resulta abrumadora la capacidad anticipatoria que tiene el epígrafe al texto. En las muchas discusiones sobre la doble naturaleza de la novela (el texto es la reescritura de la novela de Gatsby, que deviene en la novela de Nick), nunca se pone de manifiesto que la primera novela que comienza es la de Gatsby (en el epígrafe) y no la de Nick, por mucho que haya triunfado su canónico «In my younger and more vulnerable years...» (FITZGERALD, 1990: 7). Ya en el epígrafe se plantean códigos concretos como es el ritmo cromático de la novela (la aureola decadente de Gatsby, que está plasmada en su casa dorada, las brillantes luces de sus fiestas, sus trajes color amarillo, su pelo rubio, su tono bronceado, su Rolls color crema, etc.), el tema de la búsqueda (the Quest), la motivación amorosa, la naturaleza obsesiva del héroe (de naturaleza monomaníaca e inextricablemente unida al tema del tiempo) además de la ya citada metáfora del saltimbanqui o el bufón (recuérdese que Trimalchio in West Egg era uno de los títulos que Scott Fitzgerald barajó para la novela), la ulterior definición de Daisy como «the king's daughter, the golden girl» ayuda a descifrar esta última connotación del epígrafe («High in a white palace the king's daughter, the golden girl» (FITZGERALD, 1990: 115).
} 
midnight, while his station wagon scampered like a brisk yellow bug to meet all trains» (FITZGERALD, 1990: 41).

Automóviles hay de todos los tipos: Rolls Royce amarillos, coupés azules, limusinas blancas, tétricas berlinas con ruedas de repuesto pintadas de negro, furgonetas de reparto, taxis, carricoches y un largo, muy largo, etc. ¿Qué peso específico tiene el automóvil en la novela? Las tramas de cohesión social — léase comunitaria - victoriana (la red de caminos que articula el espacio en Tess of the D'Urverbilles, la intrincada malla social de Middlemarch, o incluso, apurando mucho, aquella de The House of Mirth) dan paso aquí a una red de automóviles y carreteras que cumple una triple función: en primer lugar, actúa como articulación física del espacio novelesco (el Queensboro Bridge, Ventura Road, la autopista del valle de las cenizas), en segundo lugar, desempeña un papel performativo crucial en el plano narrativo (la tragedia se desencadena con y por el atropello de Myrtle) y, en fin, sirve como símbolo de la responsabilidad social.

Al final del capítulo III, Nick, la voz autorizada de la comunidad, viaja de acompañante en el coche de Jordan. La conducción temeraria de la golfista casi provoca el atropello de un peatón —de hecho, «un trabajador» (FITZGERALD, 1990: 59—. Nick responde:

"You're a rotten driver," I protested. "Either you ought to be more careful or you oughtn't to drive at all."

"I am careful."

"No, you're not."

"Well, other people are," she said lightly.

"What's that got to do with it?"

"They'll keep out of my way," she insisted. "It takes two to make an accident."

"Suppose you met somebody just as careless as yourself."

"I hope I never will,» she answered. "I hate careless people. That's why I like you" (FITZGERALD, 1990: 59).

La cualidad que Nick desprecia en los miembros más cercanos de su comunidad es la despreocupación: «They were careless people, Tom and Daisy - they smashed up things and creatures and then retreated back into their money or their vast carelessness or whatever it was that kept them together, and let other people clean up the mess they had made...» (FITZGERALD, 1990: 170). Jordan Baker sirve aquí como ejemplo elocuente de personaje que no acepta su responsabilidad para con la comunidad. Pero no es el único: para ser justos, en lo que respecta al tema de las responsabilidades sociales, no hay actante (fuera de Nick Carraway) que pueda declararse responsable para con su comunidad: Daisy atropella a Myrtle, pero no confiesa su homicidio; es más, ni siquiera detiene el coche. Tom tampoco tiene reparos en ocultar el hecho a George Wilson. Tom, además, ya se había visto envuelto en el escándalo de un atropello en Chicago, cuando llevaba de acompañante a una de sus amantes (FITZGERALD, 1990: 170). Owl Eyes se ve envuelto en un violento accidente a la salida de la fiesta en casa de Gatsby (FITZGERALD, 1990: 55). Incluso Gatsby hace uso de sus contactos en la política municipal para librarse de una multa por exceso de velocidad, mientras que su socio, Wolfshiem, se representa directamente como un delincuente al margen de cualquier sentido de responsabilidad social. En efecto, este no conduce, pero no 
le hace falta para delinquir y salir impune: se trata del hombre que amañó las series de $b a$ seball de 1919 jugando con la ilusión «de millones y millones de personas».

La red automovilística lleva al lector a cuestionar la naturaleza de la responsabilidad que motiva a los personajes principales de la novela. La responsabilidad social que se articula en torno a esa red genera conexiones muy estables en el grueso de la comunidad. Y estas son, siempre en última instancia, las que ayudan a medir el grado de vinculación identitaria que cada personaje, de forma individual, experimenta con relación a la comunidad. El caso del automóvil es, en este sentido, particularmente interesante, pues gracias a sus dos principales niveles de significado (el automóvil como valor de cambio, como símbolo de riqueza (de riqueza vacua) y como origen cabal de la responsabilidad social) logra convertirse en verdadero centro gravitatorio de la comunidad de la novela.

\section{THE ROTTEN DRIVER; THE ROTTEN CROWD; TRIMALCHIO IN WEST EGG}

El contradictorio equilibrio de pulsiones que caracteriza la personalidad de Nick se desestabiliza en el momento en que este constata la actitud descuidada que caracteriza al resto de miembros del reparto. Su decisión final de volver al «roaring Midwest» desequilibra la balanza de sus deseos a favor del cómodo nicho de la comunidad. Desde este punto de vista, la lección de Marlow (aceptar la pulsión individual como origen moral del comportamiento del sujeto) no parece haber calado en la conciencia del narrador de Gatsby. ¿Dónde está, entonces, el elemento morboso? Hay un interesante parecido entre los casos de Jim, Gatsby, Tom, Daisy y Jordan (más en el caso de los dos primeros que de los otros tres), que, sin embargo, no acaba de explicitarse del todo. El parecido tiene que ver con el concepto de lo morboso que expliqué al principio del artículo.

Al igual que la turista italiana de Conrad, Nick Carraway detecta muy bien el elemento morboso que desestabiliza los valores éticos de la responsabilidad, el sentido del deber y la conciencia social. Llama la atención, a propósito de esto, la función de un personaje que todavía no había entrado en esta discusión: se trata de George Wilson. El garaje de Wilson es el lugar crítico al que confluyen los distintos elementos de la tragedia. Antes del accidente, por la tarde, Tom, Nick y Jordan ya habían pasado por el garaje de Wilson (poco después, por cierto, de que este descubriera la infidelidad de su esposa). Es entonces cuando se enteran de que Wilson está enfermo:

The relentless beating heat was beginning to confuse me and I had a bad moment there before I realized that so far his suspicions hadn't alighted on Tom. He had discovered that Myrtle had some sort of life apart from him in another world and the shock had made him physically sick. I stared at him and then at Tom, who had made a parallel discovery less than an hour before-and it occurred to me that there was no difference between men, in intelligence or race, so profound as the difference between the sick and the well. Wilson was so sick that he looked guilty, unforgivably guilty—as if he had just got some poor girl with child (FITZGERALD, 1990: 118; la cursiva es mía). 
Hay que hacer notar que Nick no atribuye responsabilidad a Wilson, sino más bien culpa, es decir, mala conciencia. Acostumbrado a hacer clasificaciones (con la intención, por lo general, de hallar un orden comunitario explícito: «There are only the pursued, the pursuing, the busy and the tired» (FITZGERALD, 1990: 77), Nick proporciona al lector dos categorías muy útiles para comprender la posición que, con respecto de la comunidad, mantienen los personajes de la novela: «the sick and the well» (FITZGERALD, 1990: 118). Es lógico que el rey del valle de cenizas esté enfermo. También lo estaba, según explicaba Jessie L. Weston, el Rey Pescador de la leyenda artúrica (leyenda que acaso haya llegado a Gatsby via Eliot). La propuesta mítica de la tierra baldía remite a un pasado pretercristiano - el origen del mito del Rey Pescador, no debe buscarse en el ámbito cristiano, sino más bien en la tradición de los ritos de la fertilidad o del corpus legendario celta (WESTON, 1993: 113-136; LOOMIS, 1996: 213 y ss. ${ }^{8}$ )—, pero también, paradójicamente, a un futuro idólatra moderno como diría Carlyle (1966: 25 y ss.). En efecto, la descripción del valle de cenizas apunta a un mundo en el que la divinidad, aquella que debería hallarse en el origen de la comunidad de la novelal, ha quedado reducida a un efímero significante vacío, a un gesto o una pose. Los ojos del Dr. T. J. Eckleburg dominan el valle de cenizas, sí, pero no se trata del ojo desnudo de dios, sino de los anteojos del dios muerto, en cierto modo el de Nietzsche, un dios que ha perdido su puesto como origen heterónomo y garante estructural de la comunidad. El Rey Pescador era responsable de la desventura de la comunidad por causa de su inexorable imbricación con la tierra que gobernaba. Pero la situación se revierte en el caso de Wilson, esto es, la víctima cabal de la situación económica asimétrica (la producción, la fuerza obrera elidida de la novela) que preside la comunidad de The Great Gatsby. Ahora bien, si Wilson es víctima, ¿por qué debe sentirse culpable? ¿Cuál es el origen cabal de dicha culpa?

Alfred Kazin da con la clave:

The sense of guilt is apparently more than the residue in our racial unconscious of some ancient defiance of parental and divine authority, Freud's theme in Totem and Taboo and Moses and Monotheism. It also serves as the most immediate weapon by which the intelligence deceives that part of the self that can assess the elements of experience with candid objectivity or clear self-assertion. It is the inbred weapon, the little dagger of the soul, by which we make ourselves literally in-valid when wish to remove ourselves from an intolerable situation. It is the device by which we suspend thought under the name of morality. (...) It is not only a form of evasion, but also a field of discourse. By admitting that we are guilty we often plan to shock, to reap the vibrant advantages of having gained some dramatic singularity. By our admission we suddenly command that authority which the unloved exercise by their suffering (Kazin, 1954: 171 y 174).

\footnotetext{
${ }^{8}$ Ambos autores explican, desde puntos de vista notoriamente distintos, la conexión del símbolo con la idea de la fertilidad y/o la sexualidad). La enfermedad de Wilson, por otra parte, tiene la impotencia como síntoma más relevante: «Ever had any children? Come on, George, sit still-I asked you a question. Did you ever have any children?» (FITZGERALD, 1990: 149). No es ocioso recordar aquí que el libro de Weston constituye una fuente directa (reconocida por el propio T. S. Eliot) de The Waste Land (1922).
} 
Salvando las distancias y lo que haya que salvar, Kazin expresa en términos de crítica literaria lo que Nietzsche ya había propuesto con su peculiar estilo vehemente. Recurrir a la culpa supone encerrarse, aún más si cabe, en el «cuarto de la conciencia» —el término es de «Sobre verdad y mentira en sentido extramoral» (NIETZSCHE, 2003: 17) — para evitar, de una vez por todas, exponernos a la violencia contenida en el abismo de la realidad. Sostiene Kazin «It is characteristic of us to charge ourselves with any guilt so long as it will put distance between us and the concrete reality; it is easier to suffer than to understand» (KAZIN, 1954: 174). De nuevo, el sentido de culpa, de mala responsabilidad, aparece entrecruzado con la idea de comunidad.

Ahora bien, si el enfermo, esto es, el culpable, se refugia en su culpa, aquella que se inserta en el individuo por medio de la ideología que sostiene a la comunidad, ¿no debería Nick sentirse culpable, esto es, enfermo, por haberse visto expuesto al deseo de experimentar la vida en todas sus posibilidades? Sí debiera. La sorpresa es que Nick, de hecho, llega a sentirse enfermo. Una vez consumada la tragedia, Nick se ve rodeado por toda la «careless people» que le ha ayudado a abrigar sus ambiciones más vitalistas. En esta ocasión, Nick incluye también a Jordan en el lote:

"I'll telephone for a taxi to take you home, and while you're waiting you and Jordan better go in the kitchen and have them get you some supper-if you want any." He opened the door. "Come in."

"No thanks. But I'd be glad if you'd order me the taxi. I'll wait outside."

Jordan put her hand on my arm.

"Won't you come in, Nick?"

"No thanks."

I was feeling a little sick and I wanted to be alone. But Jordan lingered for a moment more.

"It's only half past nine," she said.

I'd be damned if I'd go in; I'd had enough of all of them for one day and suddenly that included Jordan too (FITZGERALD, 1990: 135).

Parece que la enfermedad constituye un emblema de la conciencia comunitaria. Y dicha postura, tanto estética como ideológica, parece provenir y funcionar del mismo modo que en Conrad. La clave se halla, precisamente, en el pasaje anteriormente citado para postular la red de automóviles que cohesiona el grupo comunitario de referencia en la comunidad. Fitzgerald utiliza el término «rotten» solo en dos pasajes de la novela. El primero ya lo he citado. El segundo es como sigue. Tras la muerte de Myrtle, Daisy consuma su traición a Gatsby volviendo con Tom. Por la mañana, Gatsby y Nick desayunan juntos. Esa será la última vez que Nick vea a Gatsby con vida. Las palabras de despedida de Nick son estas:

"I'll call you up," I said finally.

"Do, old sport."

"I'll call you about noon."

We walked slowly down the steps.

"I suppose Daisy'll call too." He looked at me anxiously as if he hoped I'd corroborate this.

"I suppose so."

"Well-goodbye." 
We shook hands and I started away. Just before I reached the hedge I remembered something and turned around.

"They're a rotten crowd," I shouted across the lawn. "You're worth the whole damn bunch put together" (FITZGERALD, 1990: 146).

Casi de soslayo, Nick hace una interesante distinción entre el grupo de personajes formado por Tom, Jordan y Daisy y el propio Gatsby. En otras palabras, define una comunidad a la que califica de «rotten», podrida. El término me parece bastante elocuente. Estos tres personajes (Daisy, Tom y Jordan) participan de una cualidad común: los tres son «idealistas individuales», es decir, han construido un principio ideal de su yo. Susan Resneck Parr ilustra así el proceso:

The major characteres in the novel again and again embrace illusions that they know to be illusions in order to cope with their sense of hopelessness and vulnerability. [Also] the illusions they embrace are rooted typically in their pasts, even though, as Nick Carraway knows and as many of the others so painfully come to understand, 'you can't repeat the past'. [The combination of both issues] show that even as the novel makes it understandable why individuals would embrace such illusions, it also makes clear that such a choice is precarious at best, because, in the face of time's movement, human frailty, and a modern world that has become a moral and spiritual wasteland, such illusions will not suffice and in fact are likely to be destructive (RESNECK PARR, 2002: 59-60).

La indeterminación de muchas de las ilusiones a las que alude Resneck Parr tiene que ver con la imposibilidad real y creciente, por parte de los personajes, de controlar el ideal de su propio ego. Mientras Jim (y también Gatsby) «arranged his life in such a way that his identity-for-self is a secret self that is deliberately prevented from realisation in order to protect it from challenges from reality» (RESNECK PARR, 2002: 60), Tom, Daisy y Jordan no muestran ninguna voluntad por impedir la realización de su ideal. Esta, por supuesto, es del todo fútil, pues implicaría, como bien señala Resneck Parr, la actualización del pasado en los mismos términos en que ha quedado impreso en el recuerdo. (Así, el verso «Mixing memory and desire» describe muy bien el estado de conciencia en que se encuentran los tres personajes). Otro de los síntomas de este fenómeno, es, a mi modo de ver, la proyección factual de los deseos que cada personaje alberga en su ego ideal. El caso más elocuente resulta ser, como en muchas otra ocasiones, el de Daisy, la princesa dorada que, desde su alta torre, procura evitar las emociones reales en favor de los gestos ficticios: «the rest offended her — and inarguably, because it wasn't a gesture but an emotion» (FITZGERALD, 1990: 103). Jordan parece soportar mejor el grotesco equilibrio que supone vivir entre memoria y deseo. De hecho, Jordan demuestra una habilidad innata para mantener cierto equilibrio entre su ego ideal y el límite de la realidad que percibe. A pesar incluso de las apariencias: "The younger of the two was a stranger to me. She was extended full length at her end of the divan, completely motionless and with her chin raised a little as if she were balancing something on it which was quite likely to fall» (FITZGERALD, 1990: 14). Jordan mantiene su pose hasta el final: «She was dressed to play golf, and I remember thinking she looked like a good illustration»), pero, como replica Resneck Parr, «her life ultimately seems both purposeless and empty» (RESNECK PARR, 2002: 68). 


\section{CONCLUSIÓN}

Los tres personajes no son capaces de asumir sus responsabilidades sociales, por eso, cualquier comunidad que formen, estará viciada de inicio. Nick lo percibe y así lo expresa al despedirse de Gatsby. Por el contrario, tampoco son capaces de asumir sus responsabilidades individuales. Y esta diferencia es crucial. En lugar de reclamar para sí la autoría de lo ocurrido, es decir, las consecuencias de sus hechos, los tres acaban refugiándose en el orden institucional que les ofrece la comunidad a la cual han traicionado. Tom y Daisy renuevan su matrimonio y la propia Jordan se compromete de la noche a la mañana en un desesperado intento por detener la deriva de sus acciones. Tom, Daisy, y Jordan se revelan así como individuos de una comunidad grotesca que no puede funcionar cohesionada, pero tampoco por células individuales: su incapacidad para asumir cualquier tipo de responsabilidad delata su condición de podredumbre.

¿Y Gatsby? ¿En qué se diferencia, según Nick, de aquella comunidad? Gatsby guarda muchas cosas en común con Tom, Daisy y Jordan. Su motivación principal es, al igual que Lord Jim, al igual (hasta cierto punto) que Gian Battista Fidanza «Nostromo» la realización, tan poderosa como imposible, de la concepción platónica de sí mismo. $\mathrm{Y}$, al igual que estos dos referentes, sabe mantenerse firme, incluso cuando los hechos llegan a demostrarle que «of course, you can[not] repeat the past» (FITZGERALD, 1985: 106). Es razonable sostener que Gatsby, por estos motivos concretos, se revela como el gran impostor de la novela, el gran Trimalchio de West Egg. No tanto porque guarde celoso el significado vacío de su ideal egotista, cuanto porque se ve capaz de engañarse a sí mismo, asumiendo, sin embargo, la total responsabilidad individual de sus actos, por encima incluso de la realidad de los hechos: «So I walked away and left him standing there in the moonlight—watching over nothing» señala Nick para enfatizar la perseverancia de Gatsby incluso ante la evidencia de que Daisy ya no va a volver nunca con aquel). «Gatsby» sostiene Alfred Kazin, «was not a character but an idea» (KAZIN, 1985: 396). Y la ingenua predisposición que muestra para sostener su idea por encima de los límites cabales de su percepción de la realidad resulta, para Nick, la manifestación factual de la proyección del sujeto sobre la vida en términos de responsabilidad: «There must have been moments even that afternoon when Daisy tumbled short of his dreams - not through her own fault but because of the colossal vitality of his illusion» (FITZGERALD, 1990: 92). «Gatsby died without learning just how foolish he was» sostiene de Nuevo Kazin (1985: 397), enfatizando la irrealizable aspiración del protagonista; pero precisamente por la inconsciencia de este ante su trágico final, cabe reivindicarlo en los términos vitalistas que Nick sugiere (en la anterior cita), y que a ojos del narrador, justifica la redención moral del personaje. En pocas palabras, puede que el espacio comunal que exhibe la novela responda a un estadio morboso de cosas, a una disfuncional red de relaciones interpersonales en el que la irresponsabilidad de cada uno de los sujetos haga imposible, de facto, la construcción de un conjunto social pragmático, productivo y propiciatorio para el desarrollo del yo individual; pero de entre todos esos personajes, nuestro protagonista descuella en tanto emblema de un tipo de responsabilidad (la responsabilidad individual) que necesariamente lo distingue de la comunidad mórbida que conforma el resto de personajes. 
El dilema que mantienen Gatsby y Nick es, en esencia el mismo, un dilema de estirpe universal, pero también americana: abrazar los sueños de la juventud y mantener vivas las esperanzas creadas desde la inocencia o enfrentarse con la realidad de que tales sueños son esquivos e ilusorios, pues forman parte inextricable del pasado. Al final, como bien demuestra la novela, no basta con ninguna de las dos opciones. Y a la vista de ello, el mejor camino que puede tomar el individuo consiste, como sostenía el propio Fitzgerald «[in trying] to function in the face of the contradictions between the dead hand of the past and the high intentions of the future» (FITZGERALD, 1945: 69). Una comunidad, como por ejemplo la americana, que anhele mantener el equilibrio entre ambas cosas solo puede sostenerse con individuos predispuestos a aceptar dicha paradoja, esto es, a hacerse responsables de sus propios deseos, sus propios anhelos individuales (componentes últimos de sus identidades), al tiempo que aceptan la imposible realización de estos. Así, quizás, pueda reenfocarse la interpretación del final de la novela. En las últimas páginas del texto, descuella la apertura oceánica del I individual de Nick al We comunitario de América o, mejor incluso, del ser humano:

Gatsby believed in the green light, the orgastic future that year by year recedes before us. It eluded us then, but that's no matter. Tomorrow we will run faster, stretch our arms further... and one fine morning (FITZGERALD, 1990: 177-178).

En espera de esa imposible «buena mañana» «one fine morning» (FITZGERALD, 1990: 178; CONRAD, 1996: 204) ${ }^{9}$ en que se realice la imagen del ideal comunitario, la única posibilidad de redención en el contexto ideológico propuesto por el mito norteamericano consiste en llevar a cabo la enésima iteración de la responsabilidad individual, el compromiso (leal y sujeto a honor) para con la concepción ideal del yo (hechos performativos mediante): «We beat on, boats against the current, borne back ceaselessly into the past» (FITZGERALD, 1945: 178). La responsabilidad individual, esto es, la aceptación de la identidad creada por y para la reafirmación de la propia conciencia, parece ser el único remedio, en este contexto para el estado mórbido social dominante. Anótese esta idea en el catálogo de influencias que Joseph Conrad dejó en la novela.

9 La «buena mañana» que menciona el personaje de Stein en Lord Jim encarna el deseo (imposible de cumplir) de realización del yo ideal. Nick Carraway retoma la expresión para saludar la también imposible realización del nosotros ideal, es decir, la comunidad utópica que surgiría de organizar el conjunto de individuos que, eventualmente, lograsen realizar su yo ideal. Stein apela a la frustración que se genera en y desde una pulsión individual idealista. La hipótesis de Nick es, si cabe, más difícil de cumplir, pues presupone un grupo de personajes que sí han realizado su yo ideal privado. El salto pragmático del texto de Nick es, desde cierto punto de vista, siniestramente kafkiano. 


\section{REFERENCIAS}

Bentley, ERIC (1947): The Cult of the Superman, Londres, Robert Hale.

Berman, Ronald (1996): The Great Gatsby and Modern Times, Chicago, University of Illinois Press. - (2002): «The Great Gatsby and the twenties», en Prigozy, Ruth ed., The Cambridge Companion to F, Scott Fitzgerald, Cambridgue, CUP.

Bicknell, John W (1954): «The Waste Land of F. Scott Fitzgerald», The Virginia Quarterly Review, Autumn 1954, 78-96.

Blanchot, Maurice (1988): The Unavowable Community, trad. de Louis Ronald, Londres, Routledge.

Bruccoli, Mathew (1981): Some Sort of Epic Grandeur: The Life of Scott Fitzgerald, Londres, Hodder and Stoughton.

Carlyle, Thomas (1966): On Heroes, Hero-Worship and the Heroic in History, Lincoln, University of Nebraska Press.

Conrad, Joseph (1999), Heart of Darkness, ed. de Robert Hampson, Londres, Penguin.

- (1996): Lord Jim, ed. de Thomas C, Moser, Nueva York, Norton.

Fitzgerald, F, Scott (1990): The Great Gatsby, Nueva York, Penguin.

- (1945): «The Crack-Up», The Crack-Up, ed. de Edmund Wilson, Nueva York, New Directions.

Guerard, Albert, J, (1958): Conrad the Novelist, Cambridge, Harvard UP.

HAMpson, Robert (1992): Conrad: Betrayal and Identity, Londres, Macmillan.

Hillis-Miller, J, (1982): Fiction and Repetition: Seven English Novels, Cambridge, Harvard UP.

KazIN, Alfred (1951): «An American confession», en Kazin, Alfred, ed., F. Scott Fitzgerald: The Man and His Work, Nueva York, Collier-Macmillan.

- (1985): An American Procession: The Major American Writers from 1830-1930, The Crucial Century, Nueva York, Random House.

Levenson, Michael (1991): Modernism and the Fate of Individuality, Cambridge, CUP.

Loomis, Roger S, (1961): The Holy Grail, From Celtic Myth to Christian Symbol, Princeton, Princeton University Press.

Miller, James E, (1957): The Fictional Technique of Scott Fitzgerald, La Haya, Martinus Nijhoff.

Mizener, Arthur (1946): «The poet of borrowed time», en Thorpe, William, ed., Lives of Eighteen from Princeton, Princeton, Princeton University Press.

Nietzsche, Friedrich (1996): Ecce Homo, trad. de Andrés Sánchez Pascual, Madrid, Alianza.

- (2001): El gay saber, trad. de Luis Jiménez Moreno, Madrid, Espasa.

- (1994): El nacimiento de la tragedia, trad. de Andrés Sánchez Pascual, Madrid, Alianza.

- (1987), La genealogía de la moral, trad. de Andrés Sánchez Pascual, Madrid, Alianza.

- (1993): Más allá del bien y del mal, trad. de Andrés Sánchez Pascual, Madrid, Alianza.

— (2003): «Sobre verdad y mentira en sentido extramoral», Sobre verdad y mentira, trad. de Luis M. Valdés y Teresa Orduña, Madrid, Tecnos.

Resneck Parr, Susan (2002): «The idea of order at West Egg», en Matthew Bruccoli, ed., New Essays on the Great Gatsby, Cambridge, CUP.

Seldes, Gilbert (1978): «Review: The Great Gastby», en Bryer, Jackson, ed., The Great Gatsby: The Critical Reception, Nueva York, Butt Franklin and Co.

Stallman, Robert W, (1955): The Houses that James Built and Other Literary Studies, Michigan, Michigan State University Press.

TAnner, Tony, (1990): «Introduction», en Scott Fitzgerald, Francis, The Great Gatsby, Nueva York, Penguin.

Tredell, Nicolas, ed. (1997): F. Scott Fitzgerald, The Great Gatsby: Essays, Articles, Reviews, Nueva York, Columbia UP. 
Marx, Karl (1999): El capital, trad. de Wenceslao Roces, 3 vols, México D. F., Fondo de Cultura Económica.

Valls Oyarzun, Eduardo (2017): Dueños del tiempo y del espanto: Genealogía nietzscheana de la responsabilidad en la narrativa victoriana, Madrid, Escolar y Mayo.

Weston, Jessie L, (1993): From Ritual to Romance, Princeton, Princeton University Press. 